the heated face tends to retreat with a force proportional both to the density of the gas and to the area of the surface.

A calculation of the absolute value of the excess of pressure cannot be made without further hypothesis. If we were to suppose that the molecules, after collision with the heated face, rebound with the same velocities $(v+d v)$ as they would have were the temperature raised throughout, the pressure would be increased in the ratio $v+(v+d v): 2 v$ or $\mathrm{x}+d v / 2 v: \mathrm{x}$. On the other hand, if the temperature were actually raised throughout, the pressure, according to the usual gaseous laws, would be increased in the ratio $(v+d v)^{2}: v^{2}$ or $\mathrm{I}+2 d v / v: \mathbf{I}$. On this hypothesis, therefore, the unbalanced increment of pressure on the heated face is one-quarter of the increment that would be caused by a general rise of temperature to the same amount. This estimate is necessarily in excess of the truth, but it is probably of the right order of magnitude.

The supposition upon which our reasoning has been based, viz. that the mean free path of a molecule is large in comparison with the linear dimension of the vessel, has been made for the sake of simplicity, and is certainly a very extreme one. It is not difficult to recognise that in the extreme form it may be dispensed with. All that is really necessary to justify our conclusions is that the mean free path should be very large in comparison with the vane. The magnitude and distribution of the velocities with which the molecules impinge will then be independent of the fact that the face of the vane is heated, and this is all that the argument requires. The repulsion by heat of a silk fibre suspended in a moderately rare gas was, it will be remembered, verified by $O$. Reynolds.

RAYLEIGH.

\section{LIFE IN AN OASIS.'}

ATHOUGH the oases of the Libyan Desert have $A$ been frequently visited by travellers-Poncet in the seventeenth century, Browne in the eighteenth century, and Cailliaud, Drovetti, Edmonstone, Hoskins, Rohlfs, Zittel, Schweinfurth, Brugsch, and others in the nineteenth century-yet none of these authors enjoyed anything like the opportunities for the study of these remarkable districts which have fallen to the lot of the writer of the work before us. For nine years Mr. Beadnell, as a member of that active body the Egyptian Geological Survey, was engaged in the study of the Libyan Desert-including the four oases of Baharia, Farafra, Dakhla, and Kharga-while during the last three years, as director of the operations of a development company, he has resided in the last mentioned, and has carried out important observations and experiments in connection with the questions of water supply, the effects of moving masses of sand in increasing the fertility of scime areas, while overwhelming and destroying others, as well as of many other problems of great historical and antiquarian interest.

Now that the opening of a railway from Qena, a little north of Luxor, to the village of Kharga has been completed, the long and tedious camel-journey of four or five days along very rough caravan routes is avoided, and excursions from the Nile valley to this typical oasis will doubtless become much more frequent. The appearance of the present work is, therefore, very opportune. The detailed topographical and geological survey of the Libyan Desert with its oases

1 "An Ecyptian Oasis: an Account of the Oasis of Kharga in the Libyan Desert, with special reference to its History, Physical Geography, and Water Supply." By H. J. Llewellyn Beadnell. Pp. $x+24 \delta$; with 28 plate and 4 maps and sections. (London: John Murray, Igog.) Price ros. $6 d$. net.

NO. 2072, VOL. 8I] was undertaken in $1897-8$. Mr. Beadnell carried out the mapping of the Farafra and Dakhla oases, while Dr. Ball was engaged in surveying that of Kharga, the work in the Baharia Oasis being shared betweei the two investigators. Dr. Ball's map of the Kharga Oasis, with the accompanying official report, is a work of great geological value and interest, and $\mathrm{Mr}$. Beadnell's residence in the district has enabled him to add not a few important scientific details to the admirable sketch given by his colleague.

The whole Libyan Desert forms a plateau, having an elevation which, at its maximum, is but little less than 2000 feet above sea-level, yet with a fairly general slope towards the north. In this great expanse of rough limestone and flint-covered flats, with hillocks and troughs of drifting sand, the oases are deep depressions, the bottoms of which vary from Ioo to 300 feet above sea-level, surrounded, for the most part, by steep escarpments, through which only a few passes can be found which are capable of being used as camel-tracks. The whole of the deserts are underlain by great beds of sandstone (the Nubian series), forming two divisions, the "surface-water sandstones," never more than 160 feet thick, separated by 250 feet of impervious grey shales, from a much thicker series of sandstones below, the "artesianwater sandstone," which has been penetrated by borings to the depth of 400 feet.

It is by the removal, through denudation, of great masses of Eocene and. Upper Cretaceous linestones and shales that the "surface-water sandstones" have been exposed on the floors of the oases. These beds are the source of springs, and, since the districts have been occupied by human beings, a great part of the area of the Kharga Oasis was covered by shallow lakes, probably formed by the outflow from these springs. But these great lakes have been gradually dried up, and the constant drain on the limited supplies of water afforded by the "surface-water sandstones" has greatly reduced its importance as a means of irrigation. 'The accounts of the various deposits laid down in these old lakes, with their interesting contents of worked flint-flakes and pottery, are among the most novel and interesting portions of $\mathrm{Mr}$. Beadnell's book.

Far more important, however, than the surfacewater sandstones, as a source of irrigation water, are the "artesian-water sandstones," which, by means of borings, have been drawn upon from the earliest times, and constitute even now a practically inexhaustible means for promoting the cultivation of the oases. On all questions connected with the nature and amount of the yield of the different kinds of wells, the author of this book writes as an authority, and he is able to give the results of numerous ingenious experiments, carried on, in some instances, for many months. That the enormous quantities of water contained in the thick sandstones of the Nubian svstem have their source, in part in the highlands of Abyssinia, in prart in the Sudan, and to some extent in the upper waters of the Nile, where it flows over these pervious sandstones, there can be little doubt, though as to the proportional parts played by these several factors of the supply there is still much room for doubt-a doubt which can only be removed by prolonged observations.

The manner in which the ancient wells have been made, kept open, and from time to time repaired, has engaged the author's attentive study. It is surprising to learn how much has been accomplished with the aid of very simple appliances; and the long subterranean aqueducts-tunnels driven for miles into the sandstones for the purpose of increasing the flow of water-with numerous manholes up to the surface 
are wonderful monuments of persevering toil. The introduction of modern boring machines and other labour-saving contrivances may probably do much towards increasing the productiveness of the land of these oases in the future. Very interesting information is given concerning the cultivation carried on in the Kharga Oasis, and its possible extension in the future. The chief crops at present are rice, date and doum palms, and lucerne, though grapes, oranges, and other fruits are produced to a small extent. Many of these fruits, with cotton and other useful vegetable products, may be largely supplied from these districts, now that communication has been improved by the construction of the railway. In spite of the traditions concerning the existence of deposits of gold, silver, and other metals in the oases, it is probable, considering the geological structure of the district, that it is never likely to yield mineral pro. ducts of greater value than the ochre, alum, and epsom salts, which the ancients obtained in small quantities as the result of an altogether disproportionate expenditure of labour and pains.

The author, being evidently a keen sportsman, is able to give many interesting details concerning the feral life in these singular depressions of the desert. The wild mammals consist of the Dorcas gazelle, with three species of fox, and occasional striped hyænas and jackals; the birds, of sand-grouse, rock-pigeons, turtledoves, and quail. But British sportsmen must be prepared to find, among the primitive inhabitants of these lands, competing sportsmen, as enthusiastic and probably more experienced and persevering than themselves.

Although it is to the questions of water supply, and the dependent problem of agricultural development, that we look mainly for information to this work, yet its author has not been unmindful of many other points of general interest concerning the population of 8000 to 9000 souls and its distribution. They belong to Berber tribes, quite distinct from the fellahin of the Nile Valley, but with admixture from various other sources, and the author has been able, during his sojourn among them, to learn much that is of interest about their habits and customs. Thei personal characteristics, peculiarities of land- and water-tenure, their taxation and commercial methods are well described; and the features of their villages and farms are admirably illustrated. Their modes of combating their great enemy the drifting sands from the north, which tend to form ever-advancing sanddunes, receive especial attention. Some of the results attending this constant sand-drift are illustrated in the figures taken from the work.

The Egyptian kings, certainly from as far back as the eighteenth dynasty ( $1545^{-1} 350$ B.c.), have claimed dominion over these oases. When Egypt fell under NO. 2072 , VOL. 8I]
Persian rule, Cambyses sent an ill-equipped expedition to conquer the oases, but the whole army of 50,000 men, probably through the treachery of guides, perished miserably in the desert. 'The Romans long held sway in the oases, and many of the most remarkable of the monuments of the district must be referred to the period of their rule. The work before us indicates the great numbers of objects of archæological interest which are found in the district, including many Græco-Roman temples and a wonderful early-Christian necropolis, as well as very early
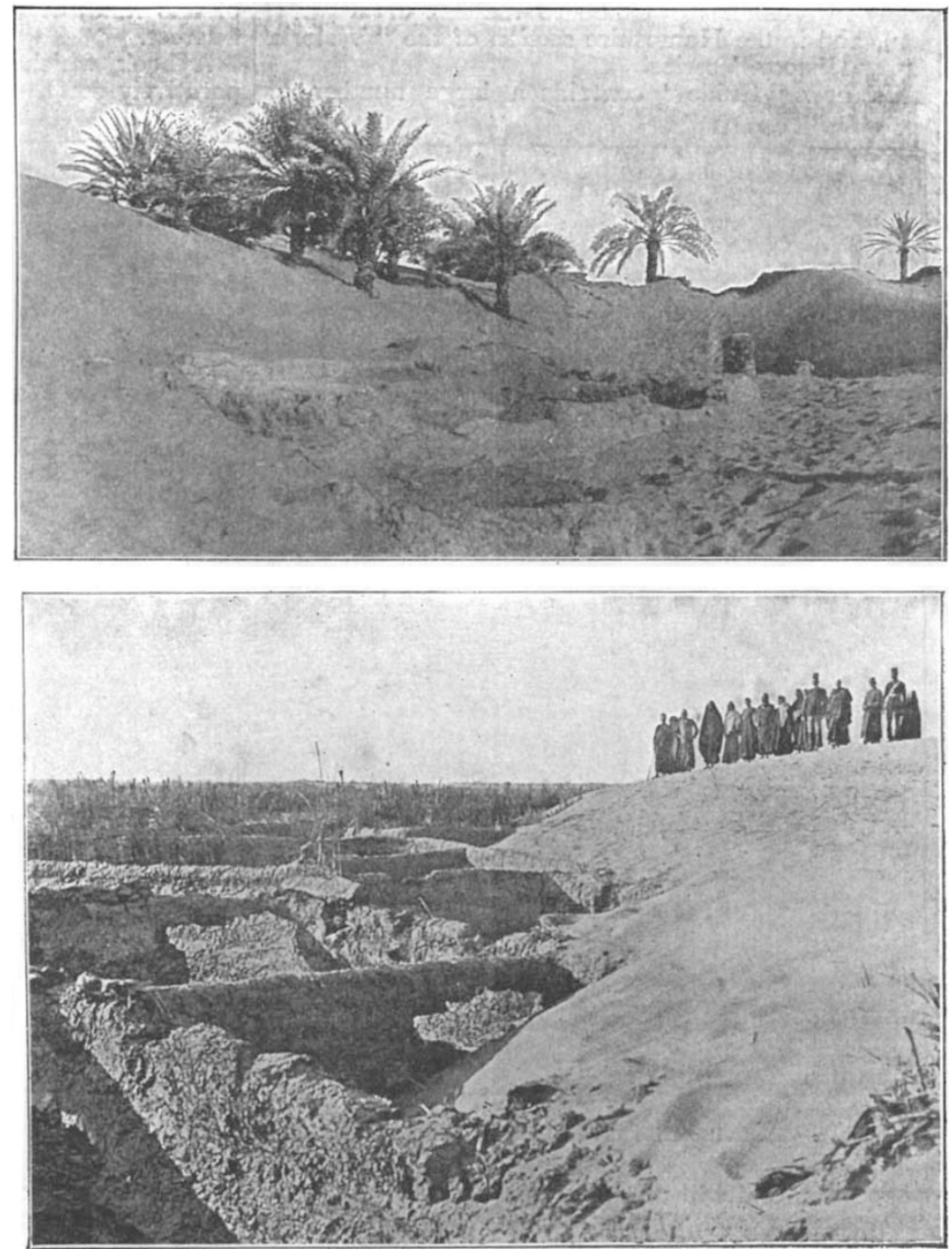

Encroachment of Sand-dunes at Meheriq. From "An Egyptian Oasis."

flint implements and pottery. We learn that $\mathrm{Mr}$. Pierpont Morgan has already had explorations commenced for the enrichment of American museums, and the completion of the railway may not improbably lead to excursions to Kharga and its temples becoming as popular as the trips to the cataracts and temples of the Nile are now. The book before us, which is dedicated to the memory of an old colleague of the author, Mr. Thomas Barrow, who fell a victim to the climate during explorations in the Sudan, ought to help to make known the points of interest at taching to these wonderful depressions in the great Sahara.

JOHN W. JUDD. 